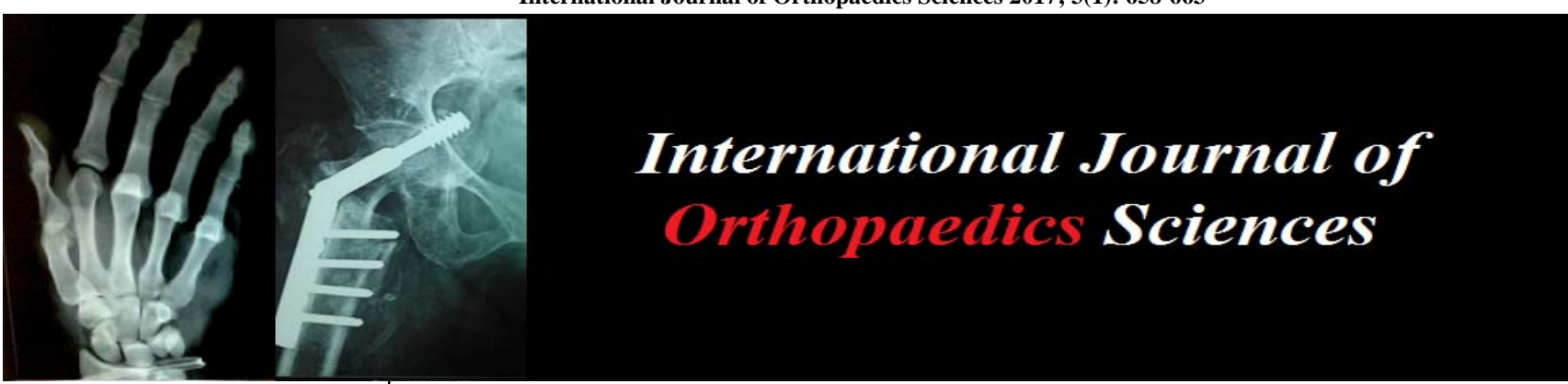

ISSN: $2395-1958$

IJOS 2017; 3(1): 658-663

(C) 2017 IJOS

www.orthopaper.com

Received: 07-11-2016

Accepted: 08-12-2016

Dr. Sunil Kumar TR

Senior Resident, ESIC Medica

College and Model Hospital \&

PGIMSR, Bangalore,

Karnataka, India

Dr. Harish YS

Senior Resident, ESIC Medical

College and Model Hospital \&

PGIMSR, Bangalore,

Karnataka, India
Correspondence

Dr. Sunil Kumar TR Senior Resident, ESIC Medical College and Model Hospital \& PGIMSR, Bangalore,

Karnataka, India

\section{Analysis of pattern of change of VAS and WOMAC between autologous bone marrow derived mesenchymal stem cells enhanced with platelet rich plasma versus platelet rich plasma in osteoarthritis knee}

\author{
Dr. Sunil Kumar TR and Dr. Harish YS
}

DOI: $\underline{\text { http://dx.doi.org/10.22271/ortho.2017.v3.i1j.97 }}$

Abstract

Introduction: Osteoarthritis $(\mathrm{OA})$ is a chronic degenerative disorder that is characterized by a loss of articular cartilage, in the synovial joints which is characterized by sclerosis subchondral bone thickening, marginal osteochondral outgrowths (osteophytes). Several risk factors have been identified, such as obesity, occupation, higher age, biomechanics and increased dynamic loading of the joint and joint injury, and invoves the weight bearing joints like hip and knee joint

Methodology: The sample size studied was 32 patients of which 16 patients in each group.The patients were selected after going through the inclusion and exclusion criteria. The patients were examined clinically regarding VAS score KOOS score and WOMAC score recorded each patient was investigated by routine blood tests investigation X ray, MRI

Results: The group 1 had baseline pain score of mean 9.38 with $(\mathrm{SD} \pm 2.187)$ and in group 2 had baseline pain score of mean $9.13(\mathrm{SD} \pm 1.586)$. Both groups were comparable and were statistically significant with $\mathrm{p}$ value of 0.571 . At final follow up, WOMAC score of group 1 had mean $1.25(\mathrm{SD} \pm 0.557)$ and group 2 had mean of $1.00(\mathrm{SD} \pm 0.00)$, It was not significant $(\mathrm{p}=0.74)$.

Conclusion: A trend towards gradual and progressive decline of the VAS is noted in the patients over the period of three follow ups from the baseline score

Keywords: VAS, WOMAC, osteoarthritis

\section{Introduction}

According to D'Ambrosia RD et al prevalence of symptomatic osteoarthritis after the age of 55 years ranges from about $30 \%$ to $50 \%$ in men and $40 \%$ to $60 \%$ in women. In the famous Framingham study, same patients were reexamined after 8 years using same set of protocol and questionnaire ${ }^{[1]}$. Of 1,438 participants in the original study, 387 (26.9\%) died prior to follow up. Of the 1,051 surviving subjects, 869 (82.7\%) participated in the follow up study (mean +/- SD age 70.8 +/- 5.0 at baseline). Rates of incident disease were 1.7 times higher in women than in men (95\% confidence interval [CI] 1.0-2.7), and progressive disease occurred slightly more often in women (relative risk $=1.4 ; 95 \%$ CI $0.8-2.5$ ) but rates did not vary by age in this sample. Among women, approximately $2 \%$ per year developed incident radiographic disease, $1 \%$ per year developed symptomatic knee OA, and about $4 \%$ per year experienced progressive knee OA. This study concluded that $2 \%$ of women per year developed radiographic knee $\mathrm{OA}$, and 1\% per year developed symptomatic, radiographic knee OA, versus $1.4 \%$ and $0.7 \%$ of men, respectively. New symptomatic OA was present if subjects developed a combination of knee symptoms and grade 2 or more osteoarthritis.

In another study ${ }^{[2]}$, women in these age groups were $39.6 \%$ and $59.1 \%$ respectively, about $40 \%$ higher than what was found in Framingham women, applying the same case definitions and radiographic methods. They recruited a sample of persons aged sixty or more, using doorto-door enumeration in randomly selected neighbourhoods in Beijing. Subjects completed a home interview including questions on knee symptoms and a hospital examination including knee radiographs obtained during weight bearing. The protocol was identical to that used in the Framingham OA Study. 
They defined a subject as having radiographic knee OA when the Kellgren/Lawrence grade was two or more in at least one knee. Symptomatic knee OA was recorded as present when knee pain was reported and the symptomatic knee had radiographic OA. They estimated the prevalence of these entities in elderly subjects in Beijing and compared it with OA prevalence in Framingham, using an age-standardized prevalence ratio. Of 2,180 age-eligible Beijing subjects contacted, knee radiographs were obtained in 1,787 (82.0\%). The prevalence of radiographic knee OA was $42.8 \%$ in women and $21.5 \%$ in men. Symptomatic knee OA occurred in $15 \%$ women and $5.6 \%$ of men. Compared with women of the same age in Framingham, women in Beijing had a higher prevalence of radiographic knee OA (prevalence ratio 1.45, 95\% confidence interval 1.31-1.60) and of symptomatic knee OA (prevalence ratio 1.43, 95\% confidence interval 1.16-1.75). The prevalence of knee OA in Chinese men was similar to that in their white US counterparts (for radiographic OA, prevalence ratio 0.90 ; for symptomatic $\mathrm{OA}$, prevalence ratio $1.02)^{[3]}$.

\section{Methodology}

Our study was a prospective randomised double blinded comparative study between use of autologous mesenchymal stem cells with platelet rich plasma (PRP) and platelet rich plasma alone in early osteoarthritis knee. A total no. of 32 patients were studied and they were randomised into two groups group 1 mesenchymal stem cells with platelet rich plasma and group 2 platelet rich plasma alone by computer generated algrorithm table each group had 16 patients.

The sample size studied was 32 patients of which 16 patients in each group. The patients were selected after going through the inclusion and exclusion criteria mentioned below.

\section{Inclusion Criteria}

1) Patients with painful knee joint

2) Grade 1 or Grade 2 Osteoarthritis knee as per Ahlbacks radiographic staging

\section{Exclusion Criteria}

1) Osteoarthritis secondary to joint inflammatory diseases (eg- rheumatoid arthritis, ankylosing spondylitis etc)

2) Patients with co-existing low back ache or any other hip joint disease.

3) Patients with other diseases, affecting the knee joint like crystal arthropathy, symptomatic chondrocalcinosis, acute synovitis, excessive joint effusion $(>100 \mathrm{ml})$, cystic disease around the knee joint(eg-popliteal cyst)

4) Advanced stage of osteoarthritis

5) Bone marrow suppression

6) Co morbidities like pregnancy, cancer, immunosuppression

All patients suitable for inclusion into the study were informed of the nature of the study in detail and a written consent was obtained.

The patients were examined clinically regarding VAS score KOOS score and WOMAC score recorded each patient was investigated by routine blood tests investigation $\mathrm{X}$ ray, MRI.

\section{Group 1}

Once the mesenchymal stem cell are ready, the PRP was prepared from the patient blood on the day of interventions. The subject was placed in supine position with knee in slight flexion and under full aseptic precautions 8-10 ml PRP was mixed with around 2-3 $\mathrm{ml}$ of autologous cultured mesenchymal stem cell and injected by lateral approach with an 18-20 $\mathrm{G}$ needle followed by $2 \mathrm{ml}$ of calcium chloride injected. After $30 \mathrm{~min}$ of observation the patient was discharged, advised three day antibiotics and paracetamol for analgesia.

\section{Group 2}

The subject was placed in supine position with knee in slight flexion and under full aseptic precautions 8-10 $\mathrm{ml}$ of PRP was injected by lateral approach with an 18-20 G needle followed by $2 \mathrm{ml}$ calcium chloride. After $30 \mathrm{~min}$ of observation the patient was discharged, and advised three day course of antibiotics and analgesia.

\section{Results}

The distribution of visual analogue scores for pain (VAS) for the patients at the time of baseline of both groups (preinjection VAS), 6 weeks (VAS1) and 6 months (VAS2) and at final follow up (VAS 3 ) are represented in the figures.

The mean VAS baseline in group1 was 58.13 ( $\mathrm{SD} \pm 10.468)$ and in group 2 was 59.38 ( $\mathrm{SD} \pm 6.801)$ which were comparable. It was statistically insignificant with $\mathrm{p}$ value of 0.919 .

At $1^{\text {st }}$ follow up at 6 weeks the Mean VAS of group1 was 41.88 ( $\mathrm{SD} \pm 11.673$ ) while that of group 2 was 52.50, ( $\mathrm{SD} \pm 9.309)$. This difference was statistically significant with $\mathrm{p}$ value of 0.006 .

At $2^{\text {nd }}$ follow up at 6 months mean VAS of group 1 was 35.00 $(\mathrm{SD} \pm 11.54)$ and that of group 2 was $47.50(\mathrm{SD} \pm 11.547)$. This difference was also significant with $\mathrm{p}$ value of 0.02 .

At final follow up mean VAS was $30.63(\mathrm{SD} \pm 8.539)$ in group 1 and in group 2 mean VAS 40.63(SD \pm 7.719$)$. This was statistically significant with $\mathrm{p}$ value 0.003 .

Table 1: Visual Analogue Scores in two groups on follow up

\begin{tabular}{|c|c|c|c|c|c|}
\hline \multirow{2}{*}{ VAS } & \multicolumn{2}{|c|}{ Group 1 } & \multicolumn{2}{c|}{ Group 2 } & \multirow{2}{*}{ p-value } \\
\cline { 2 - 5 } & Mean & S.D. & Mean & S.D. & \\
\hline Baseline & 58.13 & 10.468 & 59.38 & 6.801 & .919 \\
\hline Follow up 1 & 41.88 & 11.673 & 52.50 & 9.309 & $.006^{* *}$ \\
\hline Follow up 2 & 35.00 & 11.547 & 47.50 & 8.563 & $.002^{* *}$ \\
\hline Final Follow up & 30.63 & 8.539 & 40.63 & 7.719 & $.003^{* *}$ \\
\hline
\end{tabular}

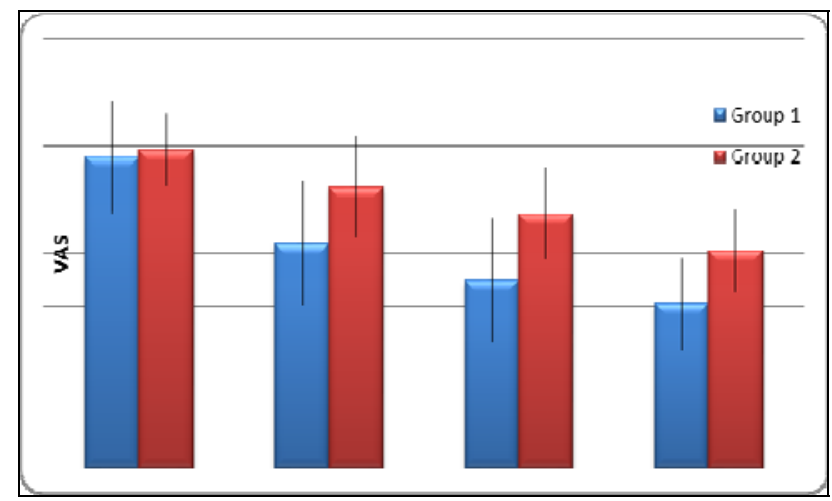

Fig 1: Visual Analogue Scores in two groups

A trend towards gradual and progressive decline of the VAS is noted in the patients over the period of three follow ups from the baseline score.

Statistical analyses for evaluating the significance of the mean VAS at follow ups as compared to the mean baseline VAS of both groups was performed by the Mann-Whitney U test and Wilcoxon W test. The analyses were done between the pairs:

1. Baseline VAS (VASBL) vs VAS at $1^{\text {st }}$ follow up (VAS1)

2. Baseline VAS (VASBL) vs VAS at $2^{\text {nd }}$ follow up (VAS2) 
3. VAS at $1^{\text {st }}$ follow up (VAS1) vs VAS at $2^{\text {nd }}$ follow up (VAS 2)

4. VAS at final follow up vs VAS baseline

A $p$ value of $<0.05$ was taken as the cut-off for significance of the test.

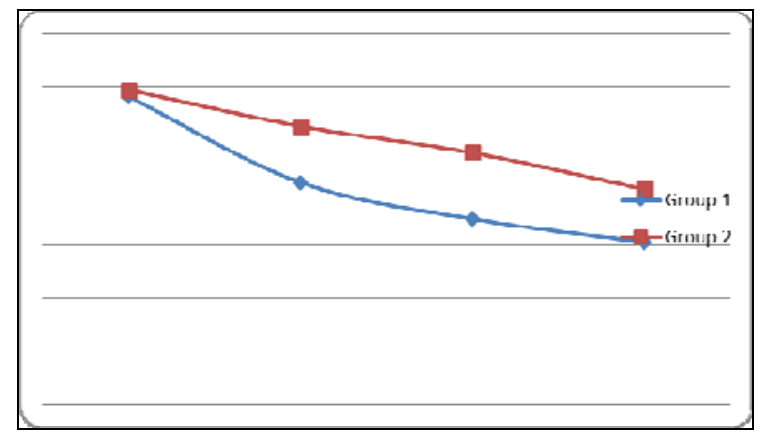

Fig 2: Graph showing the trend of VAS

There are a total of 5 questions in WOMAC regarding pain, with each question being given a value ranging from 0 to 4 . So the pain score can range from 0 to 20 . The scores in the three follow ups were compared with the pre injection scores and the trend studied, to understand the effect of treatment on pain parameter.

The group 1 had baseline pain score of mean 9.38 with $(\mathrm{SD} \pm 2.187)$ and in group 2 had baseline pain score of mean 9.13 ( $\mathrm{SD} \pm 1.586)$. Both groups were comparable and were statistically significant with $\mathrm{p}$ value of 0.571 .

At $1^{\text {st }}$ follow up group1 had score of mean 6.19, $(\mathrm{SD} \pm 1.1 .047)$ and while in group 2 had mean 3.19, ( $\mathrm{SD} \pm 1.377)$. However they were statistically significant with $\mathrm{p}$ value 0.29 .

At 2nd follow up group 1 had mean of $5.56(\mathrm{SD} \pm 1.590)$ and group 2 had mean of $6.81(\mathrm{SD} \pm 1.642)$. It was statistically significant with $\mathrm{p}$ value 0.035 .

At final follow up group 1 had mean of $3.69(\mathrm{SD} \pm 0.873)$ and in group 2 had mean of $4.56(\mathrm{SD} \pm 1.094)$. It was statistically significant with $\mathrm{p}$ value 0.021

Table 2: Means of Womac Pain on follow up in two groups

\begin{tabular}{|c|c|c|c|c|c|}
\hline \multirow{2}{*}{ Womac: Pain } & \multicolumn{2}{|c|}{ Group 1 } & \multicolumn{2}{c|}{ Group 2 } & \multirow{2}{*}{ p-value } \\
\cline { 2 - 5 } & Mean & S.D. & Mean & S.D. & \\
\hline Baseline & 9.38 & 2.187 & 9.13 & 1.586 & .571 \\
\hline Follow up 1 & 6.19 & 1.047 & 7.19 & 1.377 & $.029^{*}$ \\
\hline Follow up 2 & 5.56 & 1.590 & 6.81 & 1.642 & $.035^{*}$ \\
\hline Final Follow up & 3.69 & .873 & 4.56 & 1.094 & $.021^{*}$ \\
\hline
\end{tabular}

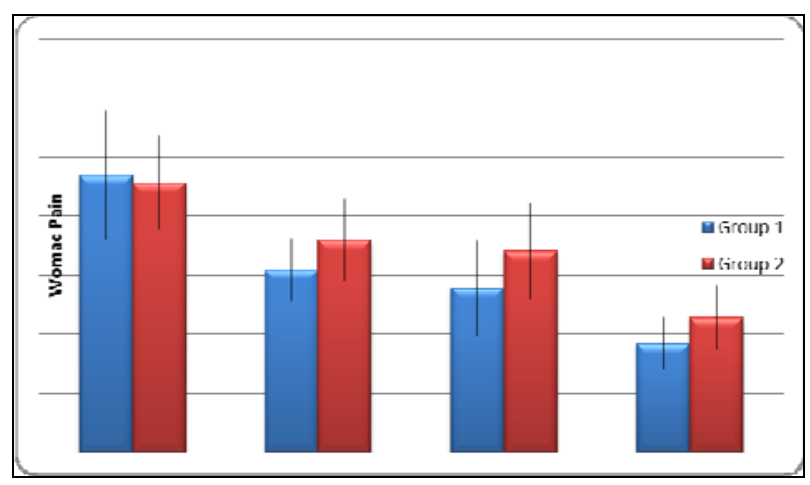

Fig 3: Means of Womac Pain on follow up in two groups

There are a total of 2 questions in WOMAC regarding stiffness, with each question being given a value ranging from 0 to 4 . So the stiffness scores can range from 0 to 8 . The scores in the three follow ups were compared with the pre injection scores and the trend studied, to understand the effect of treatment on stiffness parameter.

At the baseline group 1 had mean stiffness score of 2.56, $(\mathrm{SD} \pm 1.209)$ while group 2 had mean $1.81(\mathrm{SD} \pm 0.750)$ and both groups were comparable in stiffness at baseline and were statistically not significant with $\mathrm{p}$ value 0.082 .

At $1^{\text {st }}$ follow up group1 had mean stiffness 1.38 ( $\left.\mathrm{SD} \pm 0.619\right)$ while group 2 had mean 1.31 ( $\mathrm{SD} \pm 0.479$ ).It was not significant at $1^{\text {st }}$ follow up with $p$ value 0.907 .

At $2^{\text {nd }}$ follow up group 1 had mean stiffness of 1.44 ( $\mathrm{SD} \pm 0.814$ ) and group 2 had mean of 1.25 ( $\mathrm{SD} \pm 0.447)$. It was not significant statistically $(\mathrm{p}=0.630)$.

At final follow up group 1 had mean $1.25(\mathrm{SD} \pm 0.557)$ and group 2 had mean of $1.00(\mathrm{SD} \pm 0.00)$, It was not significant $(\mathrm{p}=0.74)$.

Table 3: Stiffness Score on follow in two groups

\begin{tabular}{|c|c|c|c|c|c|}
\hline \multirow{2}{*}{ Stiffness } & \multicolumn{2}{|c|}{ Group 1 } & \multicolumn{2}{c|}{ Group 2 } & \multirow{2}{*}{ p-value } \\
\cline { 2 - 5 } & Mean & S.D. & Mean & S.D. & \\
\hline Baseline & 2.56 & 1.209 & 1.81 & .750 & .082 \\
\hline Follow up 1 & 1.38 & .619 & 1.31 & .479 & .907 \\
\hline Follow up 2 & 1.44 & .814 & 1.25 & .447 & .630 \\
\hline Final Follow up & 1.25 & .577 & 1.00 & .000 & .074 \\
\hline
\end{tabular}

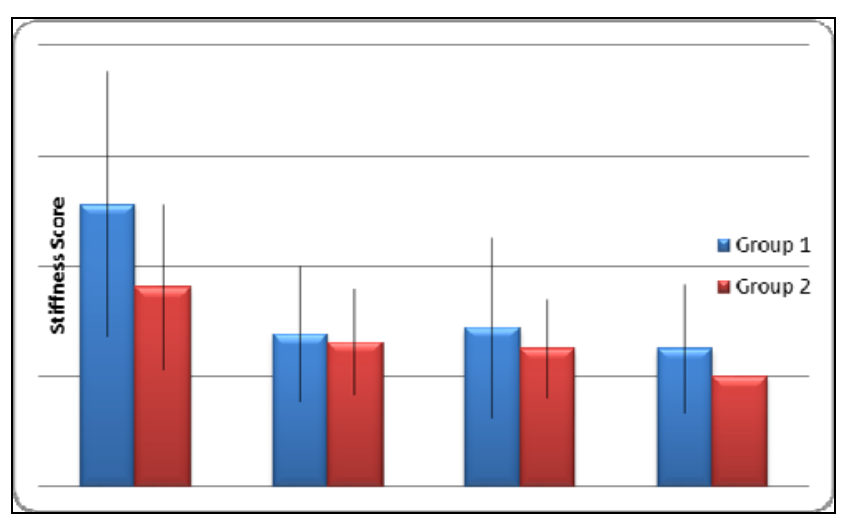

Fig 4: Stiffness Score on follow in two groups

There are a total of 17 questions in WOMAC regarding Physical Function, with each question being given a value ranging from 0 to 4 . So the Global function score can range from 0 to 68 . The scores in the three follow ups were compared with the pre injection scores and the trend studied, to understand the effect of treatment on Global function parameter.

At baseline group 1 had mean of $14.56(\mathrm{sd} \pm 5.266)$ and group 2 had mean 13.75, $(\mathrm{SD} \pm 4.171)$. Both groups were comparable at baseline with $\mathrm{p}$ value of 0.796 which was insignificant statistically.

At $1^{\text {st }}$ follow up group 1 had mean Physical function WOMAC $11.69(\mathrm{SD} \pm 6.560)$, group 2 mean was $12.00(\mathrm{SD} \pm 2.989)$ It was statistically insignificant ( $\mathrm{p}=0.925)$ at first follow up.

At $2^{\text {nd }}$ follow up mean $12.56(\mathrm{SD} \pm 4.396)$ in group 1 and mean $11.31(\mathrm{SD} \pm 2.120)$ in group 2 were observed, which was insignificant statistically with $\mathrm{p}$ value of 0.543 .

At final follow up mean Physical function of womac in group 1 was $10.63(\mathrm{SD} \pm 3.423)$ and group 2 was $9.69(\mathrm{SD} \pm 1.815)$. It was statistically insignificant $(\mathrm{p}=0.634)$. 
Table 4: Difficulty performing daily activities score in two groups

\begin{tabular}{|c|c|c|c|c|c|}
\hline \multirow{2}{*}{$\begin{array}{c}\text { Difficulty performing } \\
\text { daily activities }\end{array}$} & \multicolumn{2}{|c|}{ Group 1 } & \multicolumn{2}{c|}{ Group 2 } & \multirow{2}{*}{$\begin{array}{c}\text { p- } \\
\text { value }\end{array}$} \\
\cline { 2 - 5 } & Mean & S.D. & Mean & S.D. & .796 \\
\hline Baseline & 14.56 & 5.266 & 13.75 & 4.171 & .790 \\
\hline Follow up 1 & 11.69 & 6.560 & 12.00 & 2.989 & .925 \\
\hline Follow up 2 & 12.56 & 4.396 & 11.31 & 2.120 & .543 \\
\hline Final Follow up & 10.63 & 3.423 & 9.69 & 1.815 & 0.634 \\
\hline
\end{tabular}

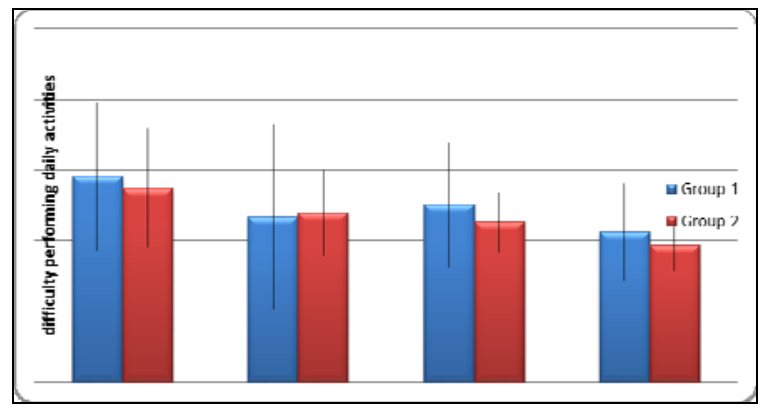

Fig 5: Difficulty performing daily activities score in two groups

There are a total of 24 questions in WOMAC which includes 5 pain questions, 2 stiffness questions and 17 Global function questions, with each question being given a value ranging from 0 to 4 . So the total WOMAC score can range from 0 to 94. The scores in the three follow ups were compared with the pre injection scores and the trend was followed to understand the effect of treatment on Global function parameter.

The group 1 had mean global womac of $26.50(\mathrm{SD} \pm 5.279)$ and Group 2 had mean global womac of $24.69(\mathrm{SD} \pm 5.186)$ at baseline value, both groups are comparable and statistically insignificant ( $\mathrm{p}=0.373)$.

At $1^{\text {st }}$ follow up at 6 weeks group 1 had mean global WOMAC of $19.25(\mathrm{SD} \pm 7.234)$ while that of group 2 had mean 20.50 $(\mathrm{SD} \pm 4.050)$. At $1^{\text {st }}$ follow up insignificant statistically with $\mathrm{p}$ value 0.650 .

At $2^{\text {nd }}$ follow up at 6 months group 1 had mean of 19.19 $(\mathrm{SD} \pm 4.199)$ and group 2 had mean $19.38(\mathrm{SD} \pm 3.160)$ It was statistically insignificant at $2^{\text {nd }}$ follow up $(\mathrm{p}=0.850)$.

At final follow up group 1 had mean of $15.56(\mathrm{SD} \pm 3.48)$ and group 2 had mean $15.25(\mathrm{SD} \pm 2.17)$ It was statistically insignificant with $\mathrm{p}$ value of 0.924 .

Table 5: Global Womac Score in two groups

\begin{tabular}{|c|c|c|c|c|c|}
\hline \multirow{2}{*}{$\begin{array}{c}\text { global } \\
\text { Womac }\end{array}$} & \multicolumn{2}{|c|}{ Group 1 } & \multicolumn{2}{c|}{ Group 2 } & \multirow{2}{*}{$\begin{array}{c}\text { p- } \\
\text { value }\end{array}$} \\
\cline { 2 - 5 } & Mean & S.D. & Mean & S.D. & .373 \\
\hline Baseline & 26.50 & 5.279 & 24.69 & 5.186 & .373 \\
\hline Follow up 1 & 19.25 & 7.234 & 20.50 & 4.050 & .650 \\
\hline Follow up 2 & 19.19 & 4.199 & 19.38 & 3.160 & .850 \\
\hline $\begin{array}{c}\text { Final Follow } \\
\text { up }\end{array}$ & 15.5625 & 3.48270 & 15.2500 & 2.17562 & .924 \\
\hline
\end{tabular}

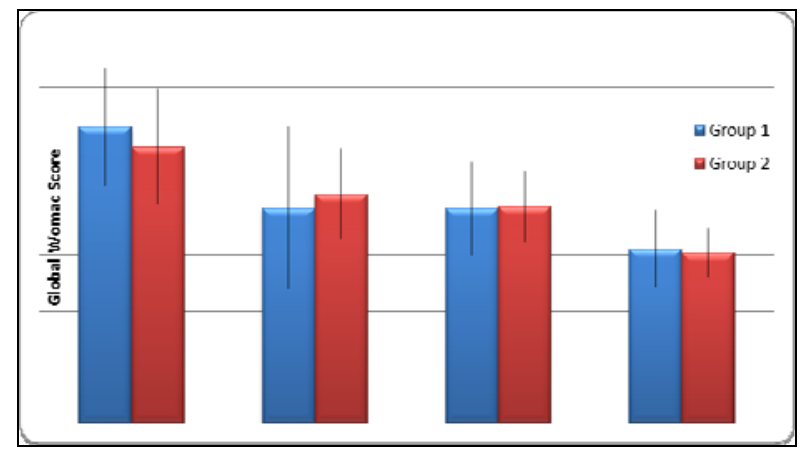

Fig 6: Global Womac Score in two groups
In our study the group 1 had the mean percentage change in the VAS score from baseline to $1^{\text {st }}$ follow up was 25.92 $(\mathrm{sd} \pm 22.166)$ and baseline to $2^{\text {nd }}$ follow up was 39.52 $(\mathrm{sd} \pm 16.844)$ and follow up 1 to $2^{\text {nd }}$ follow up was 15.788 $(\mathrm{SD} \pm 16.53)$ at final follow up $46.369(\mathrm{SD} \pm 14.19)$ and $2 \mathrm{nd}$ follow up to final follow up was 10.315 ( $\mathrm{SD} \pm 12.54$ ) and $\mathrm{In}$ group 2 at baseline mean percentage change in the VAS score from baseline to $1^{\text {st }}$ follow up was $11.63(\mathrm{SD} \pm 11.541)$, and baseline to $2^{\text {nd }}$ follow up was $9.13(\mathrm{SD} \pm 9.139)$ and $1^{\text {st }}$ follow up to $2^{\text {nd }}$ follow up was $8.86(\mathrm{SD} \pm 11.84)$ and baseline to final follow up was31.60 $(\mathrm{SD} \pm 10.24)$ and 2 nd follow up to final follow up was $13.85(\mathrm{SD} \pm 12.42)$ respectively.

Table 6: Percentage change of VAS score

\begin{tabular}{|c|c|c|c|c|c|}
\hline Percent Change & \multicolumn{2}{|c|}{ Group 1 } & \multicolumn{2}{c|}{ Group 2 } & $\begin{array}{c}\text { p- } \\
\text { value }\end{array}$ \\
\cline { 2 - 5 } & Mean & S.D. & Mean & S.D. & .029 \\
\hline $\begin{array}{c}\text { Baseline to Follow } \\
\text { up 1 }\end{array}$ & 25.922 & 22.166 & 11.636 & 11.541 & .000 \\
\hline $\begin{array}{c}\text { Baseline to Follow } \\
\text { up 2 }\end{array}$ & 39.523 & 16.844 & 20.178 & 9.139 & .002 \\
\hline $\begin{array}{c}\text { Baseline to Final } \\
\text { Follow up }\end{array}$ & 46.369 & 14.197 & 31.607 & 10.249 & .002 \\
\hline $\begin{array}{c}\text { Follow up 1 to } \\
\text { Follow up 2 }\end{array}$ & 15.788 & 16.536 & 8.869 & 11.846 & 0.184 \\
\hline $\begin{array}{c}\text { Follow up 2 to Final } \\
\text { Follow up }\end{array}$ & 10.312 & 12.549 & 13.854 & 12.423 & .535 \\
\hline
\end{tabular}

The Percentage change in womac pain score in group 1 from baseline to $1^{\text {st }}$ follow up was 32.04 , at $2^{\text {nd }}$ folowup 35.97 and at final follow up was 57.63. and from $1^{\text {st }}$ follow up to $2^{\text {nd }}$ follow up was 7.23and $2^{\text {nd }}$ follow up to final follow up was 27.91 and group 2 Percentage change in womac pain score from baseline to $1^{\text {st }}$ follow up was21.63, at $2^{\text {nd }}$ folowup 25.43and at final follow up was 48.78 and from $1^{\text {st }}$ follow up to $2^{\text {nd }}$ follow up was 4.995 and $2^{\text {nd }}$ follow up to final follow up was 29.43 respectively.

Table 7: Percentage change in WOMAC pain

\begin{tabular}{|c|c|c|c|c|c|}
\hline Percent Change & \multicolumn{2}{|c|}{ Group 1 } & \multicolumn{2}{c|}{ Group 2 } & \multicolumn{1}{c|}{$\begin{array}{c}\text { p- } \\
\text { value }\end{array}$} \\
\cline { 2 - 5 } & Mean & S.D. & Mean & S.D. & \\
\hline $\begin{array}{c}\text { Baseline to Follow } \\
\text { up 1 }\end{array}$ & 32.0461 & 11.697 & 21.163 & 6.680 & .001 \\
\hline $\begin{array}{c}\text { Baseline to Follow } \\
\text { up 2 }\end{array}$ & 35.974 & 29.537 & 25.434 & 11.751 & .015 \\
\hline $\begin{array}{c}\text { Baseline to Final } \\
\text { Follow up }\end{array}$ & 57.633 & 18.669 & 48.784 & 13.534 & .037 \\
\hline $\begin{array}{c}\text { Follow up 1 to } \\
\text { Follow up 2 }\end{array}$ & 7.232 & 34.335 & 4.997 & 16.307 & .165 \\
\hline $\begin{array}{c}\text { Follow up 2 to } \\
\text { Final Follow up }\end{array}$ & 27.916 & 27.930 & 29.434 & 20.997 & .865 \\
\hline
\end{tabular}

\section{Discussion}

VAS

Mesenchymal stem cells with PRP group (group 1) had the mean VAS at baseline was 58.13, at $1^{\text {st }}$ follow up at 6 weeks was 41.88 which was a decrease of $27.95 \%$ over the baseline VAS and at $2^{\text {nd }}$ follow up at 6 months was 35.00 , which was a decrease of $39.79 \%$ over the baseline VAS, and $16.42 \%$ over the VAS at 6 weeks, and at final follow up mean VAS was 30.63 which was decrease of $47.3 \%$ from baseline and $12.48 \%$ decrease from $2^{\text {nd }}$ follow up.

PRP group (group 2) had mean VAS at baseline was 59. 38, at $1^{\text {st }}$ follow up at 6 weeks was 52.50 , which was a decrease of $11.58 \%$. And at $2^{\text {nd }}$ follow up at 6 months was 47.50 , which was a decrease of $20 \%$ over the baseline VAS, and $9.52 \%$ over the VAS at 6 weeks and at final follow up 40.63 which was 
$31.57 \%$ from baseline and $14.4 \%$ from $2^{\text {nd }}$ follow up.

Centeno et al ${ }^{[4]}$ used mesenchymal stem cell only in osteoarthritis knee showed at 3-month follow up, modified VAS pain scores decreased by $95 \%$.

In the clinical trial by Davatchi et al ${ }^{[5]}$ used mesenchymal stem cells in osteoarthritis knee and the amount of pain on VAS (100 mm scale) was 90, 80, 90 and 85. After 6 months of follow up it improved to 50, 40, 55 and 65 . The amount of improvement was $44 \%, 50 \%, 39 \%$ and $24 \%$.

Only a single study is available in the literature regarding use of mesenchymal stem cell with platelet rich plasma in osteoarthritis knee. Amgad et al ${ }^{[6]}$ in 2010 a pilot study done on 5 patients showed statistically significant improvement in symptoms over 12 months follow up, study included the Lysholm and Revised Hospital for Special Surgery Knee (RHSSK) scores, not the VAS score evaluated.

Thus in our study Mesenchymal stem cell with PRP group (group I) had significant improvement in the VAS score at 6 weeks and at 6 months and final follow up compared to the PRP group (group 2) alone.

\section{WOMAC (Western Ontario and McMaster Universities Osteoarthritis Index)}

The WOMAC is one of the most widely utilized self-report measures of lower extremity symptoms and function. It has been studied over a period of almost 30 years in many different contexts and patient populations, and there are abundant data regarding its utility and measurement properties. The WOMAC has been extensively used in the context of clinical trials. Many reviews have summarized the performance of the WOMAC with respect to responsiveness in these trials ${ }^{[7]}$.

Overall, studies have shown that the WOMAC pain and function subscales exhibit comparable or greater responsiveness to change than corresponding SF-36 subscales. Responsiveness varies according to subscales and type of intervention ${ }^{[8]}$.

Studies also support the adequacy of the measurement properties of the WOMAC, though two potential weaknesses have been debated. First, there is little evidence regarding the measurement properties of the stiffness subscale, and its testretest reliability has been low ${ }^{[9]}$. Second, some studies have found inadequate factorial validity of the WOMAC pain and physical function subscales, potentially leading to weaknesses in the ability of the physical function subscale to detect change when there is a weak association between pain and function. Mesenchymal stem cells with PRP group (group 1) had mean global WOMAC of 26.50, At $1^{\text {st }}$ follow up at 6 weeks had mean 19.25 , shows a decrease of $27.35 \%$, from base line At $2^{\text {nd }}$ follow up at 6 months had mean of 19.19 , shows a decrease of $27.58 \%$ from baseline, and final follow up 15.56 which was decrease of $41.28 \%$ from baseline and $18.916 \%$ from $2^{\text {nd }}$ follow up.

PRP only group (group 2) had mean global WOMAC at baseline was 24.69 , at $1^{\text {st }}$ follow up at 6 weeks mean was 20.50 , shows a decrease of $16.97 \%$, and at $2^{\text {nd }}$ follow up at 6 months mean was 19.38 , shows a decrease of $21.50 \%$ from the baseline, and $5.46 \%$ decrease from $1^{\text {st }}$ follow up. and mean global WOMAC at final follow up was 15.25 which shows $37.14 \%$ from baseline $21.31 \%$ decrease from $2^{\text {nd }}$ follow up.

Amgad et al ${ }^{[6]}$ in 2010 a pilot study done on 5 patients showed statistically significant improvement in symptoms over 12 months follow up, study included the Lysholm and Revised Hospital for Special Surgery Knee (RHSSK) scores, not the WOMAC score evaluated.
The mesenchymal stem cell with PRP group showed the significant improvement in the global WOMAC score at 6 weeks, 6months and at final follow up compared with the PRP group.

\section{KOOS (Knee injury and Osteoarthritis Outcome Score)}

The Knee injury and Osteoarthritis Outcome Score (KOOS) is an extension of the Western Ontario and McMaster Universities Osteoarthritis Index (WOMAC). The KOOS is a useful, reliable, valid and responsive instrument for assessment of patient-relevant outcomes in subjects with osteoarthritits ${ }^{[10]}$ Mesenchymal stem cell with PRP group (group 1) KOOS score was mean 44.75 at baseline, at $1^{\text {st }}$ follw up at 6 weeks mean was 30.31 , which was a decrease of $32.26 \%$, at 2 nd follow up mean was 30.69 , which was a decrease of $31.41 \%$ over the baseline KOOS and at final follow up mean global koos was 25.31 and $43.44 \%$ from baseline, and $17.53 \%$ decrease from second follow up.

PRP group( group 2), KOOS score was 39.56 mean at baseline, at $1^{\text {st }}$ follw up at 6 weeks mean was 29.31 , which was a decrease of $25.91 \%$, at 2nd follow up mean was 27.75 , which was a decrease of $29.85 \%$ over the baseline KOOS and at final follow up mean KOOS was 19.31 which shows $51.18 \%$ from baseline.

\section{Conclusion}

In our study correlation beteen VAS score and WOMAC score showed a positive correlation in both groups and which was significant statistically in group 2 than group 1 .

\section{References}

1. Felson DT, Zhang Y, Hannan MT. The incidence and natural history of knee osteoarthritis in the elderly. The Framingham Osteoarthritis Study. Arthritis Rheum 1995; 38:1500-5.

2. Zhang Y, Xu L, Nevitt MC. Comparison of the prevalence of knee osteoarthritis between the elderly Chinese population in Beijing and whites in the United States: The Beijing Osteoarthritis Study. Arthritis Rheum. 2001; 44:2065-71.

3. Zhang Y, Xu L, Nevitt MC. Comparison of the prevalence of knee osteoarthritis between the elderly Chinese population in Beijing and whites in the United States: The Beijing Osteoarthritis Study. Arthritis Rheum. 2001; 44:2065-71.

4. Centeno JC, Busse D, Kisiday J, Keohan c, Freeman M, KarliD et al. Increased Knee Cartilage Volume in Degenerative Joint Disease using Percutaneously Implanted, Autologous Mesenchymal Stem Cells. Pain Physician. 2008; 11:343-353

5. Davatchi F, Ahdollahi BS, Mohyeddin M, Shahran F, Nikbin B. Mesenchymal stem cell therapy for knee osteoarthritis, preliminary report of four patients.Int $\mathrm{J}$ Rheum Dis. 2011; 11(2):211-5.

6. Amgad M, Haleem, Abdel A, Dina S, Hazem MA, Laila A Rashed et al. The Clinical Use of Human CultureExpanded Autologous Bone Marrow Mesenchymal Stem Cells Transplanted on Platelet-Rich Fibrin Glue in the Treatment of Articular Cartilage Defects: A Pilot Study and Preliminary Results. Cartilage. 2010; 1:253-261.

7. Alan T, Ulrich AW, Andrew C, Francesco D, Cosimo De $\mathrm{B}$, Willem $\mathrm{F}$, Immunomodulatory properties of mesenchymal stem cells: areview based on an interdisciplinary meeting held at the Kennedy Institute of Rheumatology Division, London, UK, 2005. 
8. Bellamy N, Buchanan WW, Goldsmith $\mathrm{CH}$, Campbell J, Stitt LW. Validation study of WOMAC: a health status instrument for measuring clinically important patient relevant outcomes to antirheumatic drug therapy in patients with osteoarthritis of the hip or knee. J Rheumatol. 1988; 15:1833-40.

9. Pua YH, Cowan SM, Wrigley TV, Bennell KL. Discriminant validity of the Western Ontario and McMaster Universities Osteoarthritis index physical functioning subscale in community samples with hip osteoarthritis. Arch Phys Med Rehabil. 2009; 90:1772-7.

10. Roos EM, Roos HP, Lohmander LS, Ekdahl C, Beynnon BD. Knee Injury and Osteoarthritis Outcome Score (KOOS)-development of a self-administered outcome measure. J Orthop Sports Phys Ther. 1998; 28:88-96. 